\title{
Radial distribution of quinones in plantation teak (Tectona grandis L.f.)
}

\author{
Ganis LUKMANDARU ${ }^{1,2 *}$, Koetsu TAKAHASHI ${ }^{3}$ \\ ${ }^{1}$ Department of Forest Product Technology, Faculty of Forestry, Gadjah Mada University, 55281 Jogja, Indonesia \\ ${ }^{2}$ United Graduate School of Agricultural Science Iwate University, 020-8550 Morioka, Japan \\ ${ }^{3}$ Departement of Bioenvironment, Faculty of Agriculture, Yamagata University, 997-8555 Tsuruoka, Japan
}

(Received 9 October 2008; accepted 23 February 2009)

\section{Keywords: \\ Tectona grandis / \\ extractives / \\ tectoquinone / \\ desoxylapachol / \\ tree age}

\begin{abstract}
- Quinones are primarily responsible for the natural durability of teak.

- The previous paper in this series reported on the natural termite resistance of teak trees of different ages (8-, 30- and 51-year-old trees). In this study, the radial distribution of quinones (tectoquinone, lapachol, desoxylapachol and its isomer) and other components in the ethanol-benzene (1:2) extract were measured by means of gas chromatography.

- Significant differences in desoxylapachol or its isomer content were found among the outer heartwood of 8-, 30- and 51-year old trees, as well as between the inner and outer parts of the heartwood.

- All toxic quinone contents were positively correlated with the total extractive content. The highest correlation degree was measured in the isodesoxylapachol content.

- Although linearly related, only modest correlations were observed between the natural termite resistance parameters and the content of tectoquinone and isodesoxylapachol.
\end{abstract}

Résumé - Distribution radiale des quinones dans du teak de plantation (Tectona grandis L.f.). - Les quinones sont à l'origine de la durabilité naturelle du teak.

- Le précédant papier de la série traitait de la résistance naturelle contre les termites pour des arbres de 8,30 et 51 ans. Dans cette étude, la distribution radiale des quinones (tectoquinone, lapachol, deoxylapachol et son isomère) et des autres composés présents dans les extraits éthanol-benzène $(1: 2)$ est déterminée par chromatographie en phase gazeuse.

- Le contenu en desoxylapachol ou ses isomères présente des différences significatives en périphérie du bois de cœur des arbres de 8, 30 et 51 ans de même qu'entre la partie interne et externe du bois de cœur.

- Toutes les teneurs en quinones toxiques sont corrélées positivement avec le contenu total d'extractibles. Le degré de corrélation le plus élevé est mesuré pour la teneur en isodesoxylapachol.

- Bien qu'il existe une relation linéaire entre les paramètres de résistance naturelle aux termites et la teneur en tectoquinone et isodesoxylapachol, les corrélations observées sont modestes.

\section{INTRODUCTION}

Teak is valued for its beautiful texture, weather resistance and natural durability. These advantages have resulted in the use of teak in various applications from handicrafts to heavy construction. Teak wood from natural forests and from plantations with long rotation ages has an established reputation for outstanding quality. In Indonesia, most teak trees are harvested from plantation forests. Recently, industries traditionally reliant on wood have faced a supply shortage, which has necessitated the harvesting of younger trees from plantation and farmland stands as raw materials. In order to utilize this

*Corresponding author: ganisarema@lycos.com younger wood more effectively, basic knowledge is needed of the differences between younger and older wood that could affect its use.

The high natural durability of teak is an important characteristic that has been attributed to various extractive compounds identified in teak. Yamamoto et al. (1998) demonstrated the significant effects of teak wood extractives on wood-destroying fungi. Quinones and their derivatives have been reported to act against termite and fungal attacks (Haupt et al., 2003; Rudman and Gay, 1961; Sandermann and Simatupang, 1966; Sumthong et al., 2006; Thulasidas and Bhat, 2007). Differences in natural durability may be related to the concentration of toxic extractable substances of wood accumulation during the formation of heartwood. Unfortunately, 
little has been reported on the quantity and composition of the active compounds according to tree age.

Several studies concerning the relation between the extractive content, age, radial position and the natural durability of teak have been published (Da Costa et al., 1958; 1961; Rudman et al., 1967). Recently, one study (Lukmandaru and Takahashi, 2008) demonstrated a relationship between the natural termite resistance parameters and the level of extractive contents obtained from successive solvent extraction ( $n$-hexane, ethyl acetate and methanol) from different trees (8, 30 and 51 years old). In this paper, the radial distribution of quinones of teak was investigated on the corresponding samples of those trees to estimate the effect of extractives on the relative natural durability of the wood. The other purposes of this study were to relate the amount of the major compounds to the extractive content, as well as to relate the amount of the active compounds to previous data on natural termite resistance properties.

\section{MATERIALS AND METHODS}

\subsection{Sample preparation}

The stand characterization, site localization and climatic conditions have been described earlier (Lukmandaru and Takahashi 2008). The members of the 8-year-old group (trees 1 to 5) and 30-year-old group (trees 6 to 9) were felled from farm plantations or "community forests' in Jogja Province, while the 51-year-old group (trees 10 to 14) was harvested from the Perhutani plantation (state-owned forest) in Central Java Province. A 5-cm-thick disc was removed at approximately breast height from the trees. Each disc was divided into five parts: outer sapwood (OS), inner sapwood (IS), outer heartwood $(\mathrm{OH})$, middle heartwood $(\mathrm{MH})$ and inner heartwood $(\mathrm{IH})$. The $\mathrm{MH}$ and IH zones in the 8-year-old discs, as well as the IS zone in the 51-year-old discs, were excluded as they did not yield enough material for analysis. For each part, blocks were sawn on two opposite radii. Each block was then cut into two pieces. One piece was previously used for a termite resistance test. The remaining piece was converted into wood meal (40-60 mesh size) to determine the content and chemical composition of the extractives. The meals from two opposite radii were then combined to form a single sample in order to minimize any variation between radii.

\subsection{Total extractive content determination}

In order to extract all the main quinones in teak, the method previously described by Thulasidas and Bhat (2007) was followed. Extractives were obtained by extracting one $\mathrm{g}$ of wood meal with ethanol/benzene $(1 / 2, v / v)$ in a Soxhlet for $8 \mathrm{~h}$. After evaporating the solvent under reduced pressure, the extractives were removed, dried and weighed to determine the percentage of total extractive content based on moisture-free sawdust.

\subsection{Chemical analyses}

The extracts (concentration of $100 \mathrm{mg} \mathrm{mL}^{-1}$ ) were analyzed by GC (Hitachi Model G-3 500) under the following conditions: de- tector: FID; column: NB-1 bonded capillary $30 \mathrm{~m}$; column temperature: $120-300{ }^{\circ} \mathrm{C}$ (programing $4{ }^{\circ} \mathrm{Cmin}^{-1}$ ), detector and injector temperature at $250{ }^{\circ} \mathrm{C}$, held at $300{ }^{\circ} \mathrm{C}$ for $15 \mathrm{~min}$, carrier gas: helium. One $\mu \mathrm{L}$ of the solution was injected manually into the gas chromatograph. For quantification of individual substances, calibrations were made using known amounts of reference samples: tectoquinone (2-methyl anthraquinone, 25 753-31 Kanto Chemical), lapachol (142905 Sigma-Aldrich), 2-hydroxymethyl anthraquinone (17 241-59-7 Acros Organics), squalene (37 309-30 Kanto Chemical) and palmitic acid (32 016-30 Kanto Chemical), and the response factors were determined for each substance in relation to an internal standard (heneicosane). The amounts of the different components are expressed as percentages of oven-dried wood mass. From the contents of tectoquinone, lapachol, desoxylapachol and its isomer, the total quinone content was calculated. Based on the separate injections of four subsamples of a single batch of teak meal, the coefficient of variation for quinone contents was less than $10 \%$. This level of precision, therefore, is considered to be sufficient for wood quality investigation.

Compounds were identified by comparing their mass spectra with the literature data and the injection of standards. GC-MS (JEOL XS mass spectrometry at $70 \mathrm{eV}$ ) was used for gas chromatographic separations.

\subsection{Termite resistance test}

The natural termite resistance data were taken from the previous report. For each test, an air-dried wood block ca. $5.0(\mathrm{~L}) \times 0.8(\mathrm{~T}) \times$ $0.8(\mathrm{R}) \mathrm{cm}$ was placed on the surface of the sterile sand in a plastic cup $(5.0 \mathrm{~cm} \times 6.0 \mathrm{~cm})$. Fifty worker termites (Reticulitermes speratus Kolbe) were added to each cup. Pine blocks were used as controls. This procedure was replicated three times for each sample. The cups were stored in an environmental chamber for two weeks. Surviving termites were counted in the first week and at the end of observation. The mass loss since the start of the experiment was determined.

\subsection{Statistical analysis}

The variation in the total extractive, total quinone and individual component contents was analyzed (General Linear Models Procedure) by one-way analysis of variance (ANOVA) followed by Duncan's multiple range test $(p=0.05)$. The relationships between the independent variables were studied with a Pearson's correlation analysis. The termite survival rates (percentages) were transformed by the arcsine function for analysis. All statistical calculations were conducted using SPSS-Win 10.0.

\section{RESULTS AND DISCUSSION}

\subsection{Total extractive content determination}

The total extractive content (TEC) is presented in Figure 1. The tendency of TEC of the heartwood region in all of the tree age groups generally agrees with the data from the previous TEC obtained by successive extractions, but slight differences were observed in the sapwood region. With the exception of the $\mathrm{OH}$ region, no significant difference was found among the age groups in the extractive contents in the same part due to 


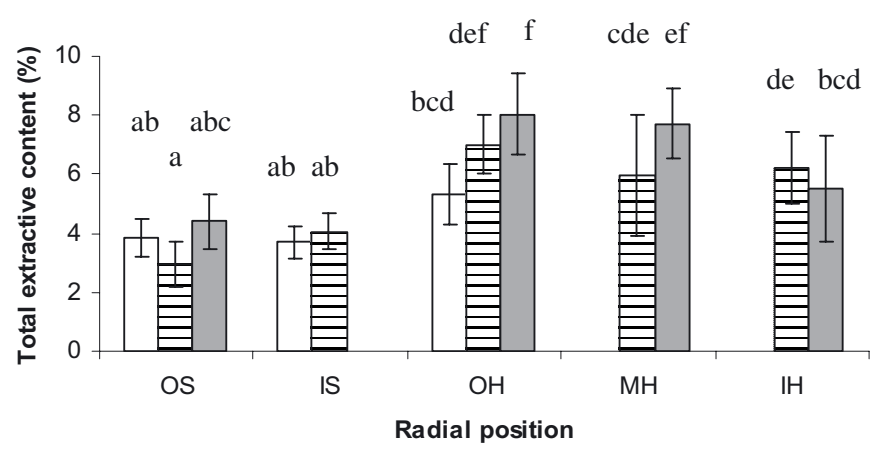

$\square$ 8-year-old 目 30-year-old $\square$ 51-year-old

Figure 1. Total extractive content $(\%)$ of teakwood by age and radial position. Mean of 5 trees ( 8 and 51 years old) and 4 trees (30 years old), with the standard deviation in the error bar. The same letters are not significantly different at $p<5 \%$ by Duncan's test. OS $=$ Outer sapwood, IS = inner sapwood, $\mathrm{OH}=$ outer heartwood, $\mathrm{MH}=$ middle heartwood, $\mathrm{IH}=$ inner heartwood.

the large variation. The maximum mean values of TEC in the $\mathrm{OH}$ of 8-, 30- and 51-year-old trees are 5.30, 7.01 and 8.04\%, respectively.

\subsection{Compound identification}

The gas chromatogram of heartwood ethanol-benzene extract is shown in Figure 2. The major compounds detected in those chromatograms were lapachol, tectoquinone, desoxylapachol and its isomer (isodesoxylapachol), squalene, tectol, palmitic acid and two unidentified compounds. All these compounds have been reported as teak components (Sandermann and Simatupang 1966 and literature cited therein). Tectol was identified by comparison of its mass spectra with those reported by Lemos et al. (1999). The peaks 1 and 4 were identified as desoxylapachol and its isomer (Perry et al., 1991; Windeisen et al., 2003). Owing to the almost identical mass spectra of the two compounds (Fig. 3), the sequence of both components in the chromatogram was uncertain. Based on their elution order, the first and second peaks were tentatively assigned as desoxylapachol and isodesoxylapachol, respectively. The molecular masses of unidentified compound 1 (UN1) and 2 (UN2) were found to be $m / e$ (base peak) = 244 and 242, respectively. The other minor compounds identified were 2-hydroxymethyl anthraquinone, 5-hydroxylapachol (Khan and Mlungwana, 1999), steroids and stearic acid.

\subsection{Compound quantification}

The quantification of major compounds is summarized in Table I. Within the wood cross-section, the quantities of most of the major compounds seem to be related to extractive contents, and follow the same general pattern, reaching maximum values in the $\mathrm{OH}$. The percentage values of tectol, lapachol, desoxylapachol and its isomer contents measured in this experiment were in the range of previous results, whereas the squalene and tectoquinone content values were generally lower than those reported in the literature (Sandermann and Dietrichs, 1959; Thulasidas and Bhat, 2007; Windeisen et al., 2003).

The presence of major compounds in the sapwood was confirmed, although at very low levels. With age, the variation in detected compounds between the sapwood region contents was small. Desoxylapachol, UN1 and UN2 were not detected in the sapwood and heartwood of 8-year-old trees, while the same compounds, along with palmitic acid, were absent from the sapwood of 51-year-old trees. In the $\mathrm{OH}$ region of 8 -year-old trees, tectoquinone, followed by lapachol, were the most abundant compounds. This composition was different from those in the 30- and 51-year-old trees, where squalene followed by desoxylapachol or tectol appeared as the highest level compounds. While the contents of most compounds were found to increase with age, no significant increase was observed in the contents of lapachol and tectoquinone in that region. In the other parts of the heartwood, only tectoquinone and squalene contents varied significantly with age. The former increased in the $\mathrm{MH}$, while the latter decreased in the $\mathrm{IH}$ region.

Among the radial sections of the heartwood of 30-year-old trees, significant differences were observed for desoxylapachol, palmitic acid and tectol content levels. Significant differences were also obtained in the palmitic acid, isodesoxylapachol, UN2, squalene and tectol contents in the heartwood of 51-year-old trees. The radial variation in the initial amounts of components can also be examined by between-tree comparisons. The OH from 8-, IH from 30- and IH from 51-year-old trees were formed in approximately the same growing seasons (juvenile region, 4-6th ring); experiments revealed the statistical differences in the desoxylapachol, UN1, UN2, squalene and tectol levels between the parts. Sandermann and Dietrichs (1959) observed that the concentration of tectoquinone is highest in the center of heartwood. Although the highest tectoquinone level was measured in the IH region of both 30- and 51-year-old trees, the ANOVA revealed that there was not a statistically significant difference with those in the $\mathrm{OH}$ and MH. Several studies have dealt with the distribution of extractive components in other species. The decrease in some active component contents in inner heartwood was noted in Thuja plicata (Nault, 1988), Pinus sylvestris (Venalainen et al., 2003) and Quercus petraea (Guilley et al., 2004).

The current study shows by examining standard deviations that there are wide variations in the amount of major constituents found in different trees, even in trees from the same sites. This means that teak may not always have a high amount of certain compounds. For instance, the amounts of tectoquinone identified in five trees of one age $(51 \mathrm{y}, \mathrm{OH})$ may vary from 0.11 to $0.59 \%$ (i.e. trees Nos. 7 and 8 ). In an earlier report, out of 13 ethanol extracts of teak specimens from various sites, desoxylapachol was detected in only two samples, while lapachol was detected in only one sample (Sandermann and Simatupang, 1966). A similar phenomenon was also observed in this study, although to a lesser extent, which inevitably caused wide variations. This result may support 


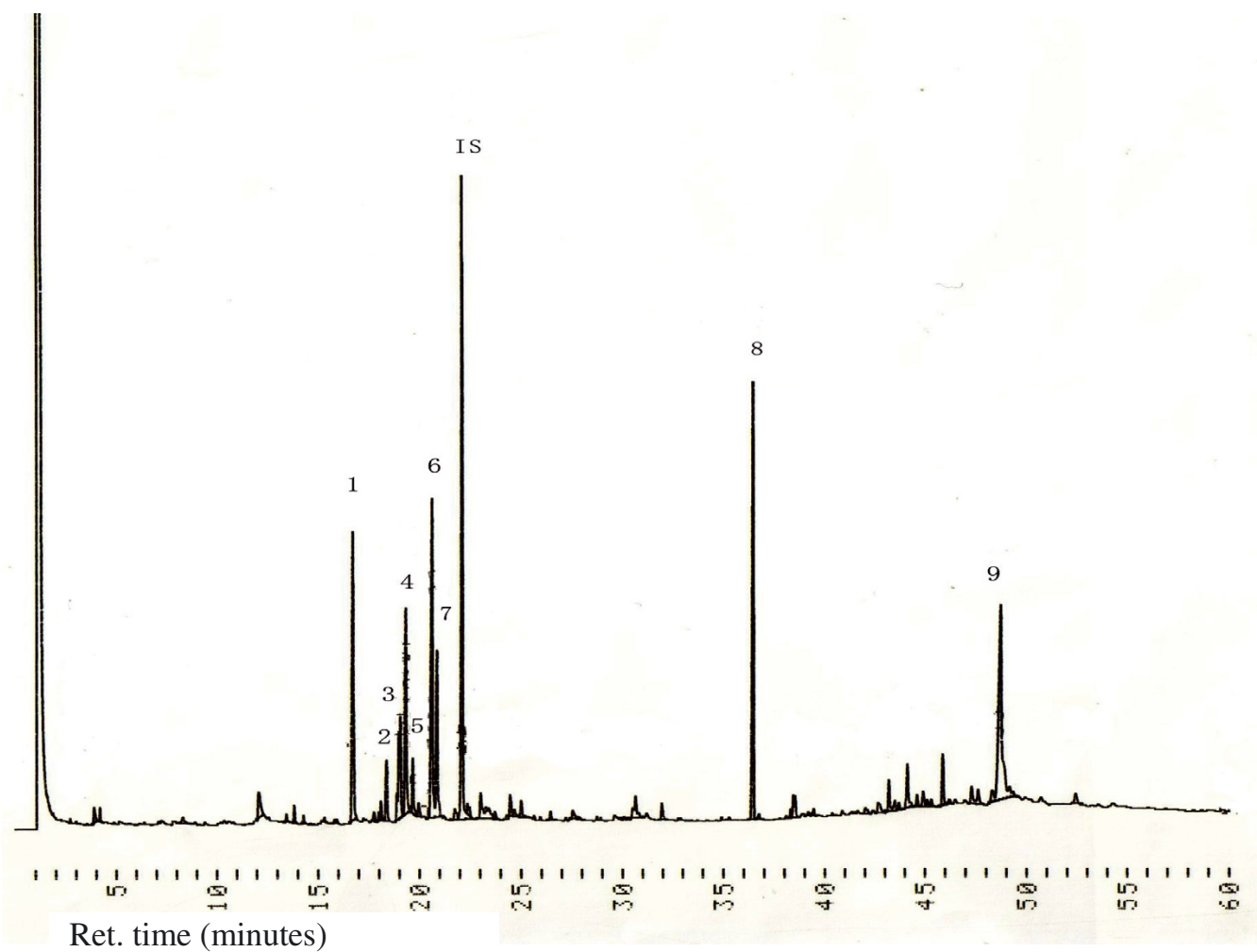

Figure 2. Gas chromatogram from ethanol-benzene extract of teak heartwood. Nine major compounds are indicated : peak $1\left(R_{t} 17.4\right)$ and $4\left(R_{t}\right.$ $20.1)=$ desoxylapachol and its isomer; peak $2\left(R_{t} 19.0\right)=$ palmitic acid; peak $3\left(R_{t} 19.7\right)=$ lapachol; peak $5\left(R_{t} 20.4\right)=$ unidentified compound 1, peak $6\left(\mathrm{R}_{\mathrm{t}} 21.3\right)$ = tectoquinone; peak $7\left(\mathrm{R}_{\mathrm{t}} 21.5\right)=$ unidentified compound 2 , peak $8\left(\mathrm{R}_{\mathrm{t}} 36.7\right)=$ squalene; and peak $9\left(\mathrm{R}_{\mathrm{t}} 49.4\right)=$ tectol, IS = internal standard (heneicosane).

earlier studies by Da Costa et al. (1958), and Bhat and Florence (2003), that found significant tree-to-tree variability in teak durability. Furthermore, due to the sampling method, it is thought that the age factor examined here may be partly correlated with site differences. Hence, tree sampling should be done on larger numbers in the same plot in order to decrease the variability in the subsequent investigations. In a previous work, Thulasidas and Bhat (2007) found a greater content of tectoquinone and napthaquinone in teak grown in a dry site than in teak grown in a wet site. Shibutani et al. (2007) reported that both environmental and genetic factors affected the quantities of antitermite compounds (cubebol, epicubebol, sandaracopimarinol and ferruginol) in the heartwood of Cryptomeria japonica. In Quercus sp., however, the effect of the local environment on volatile extractive content and ellagitannin content seems to be minor (Prida et al., 2006; 2007).

\subsection{Relationship between extractive compounds and total extractive contents}

The Pearson correlations between the TEC and various extractive compounds are presented in Table II. Correlations of a comparatively high degree were observed between the TEC and the content of isodesoxylapachol, squalene and tectol, ranging from 0.74 to 0.84 . Of the quinones, the strongest positive correlation was measured between the content of tectol and the content of isodesoxylapachol $(r=0.91)$. Moderate positive correlations were obtained between the contents of naphtaquinones (lapachol, desoxylapachol and its isomer). Between tectoquinone and the napthoquinone compounds, a moderate positive relationship was observed in tectoquinone and isodesoxylapachol content $(r=0.54)$.

It was observed in previous findings that mass loss due to termite attacks moderately correlated with $n$-hexane extractive content and TEC. As anticipated, correlation analysis revealed significantly positive values between TEC and toxic quinone levels, ranging from 0.45 with lapachol to 0.79 with isodesoxylapachol. These results may partly explain the impact of extractive content on the natural durability of teak.

\subsection{Distribution of extractives as related to natural durability}

Rudman and Gay (1959) concluded that all anthraquinones possess termiticidal properties. In a literature review, Sandermann and Simatupang (1966) mentioned that tectoquinone is the principal component responsible for natural durability against termites. Furthermore, desoxylapachol has been found to exhibit strong antitermite activity, but lapachol has only weak antitermite activity. Haupt et al. (2003) reported 


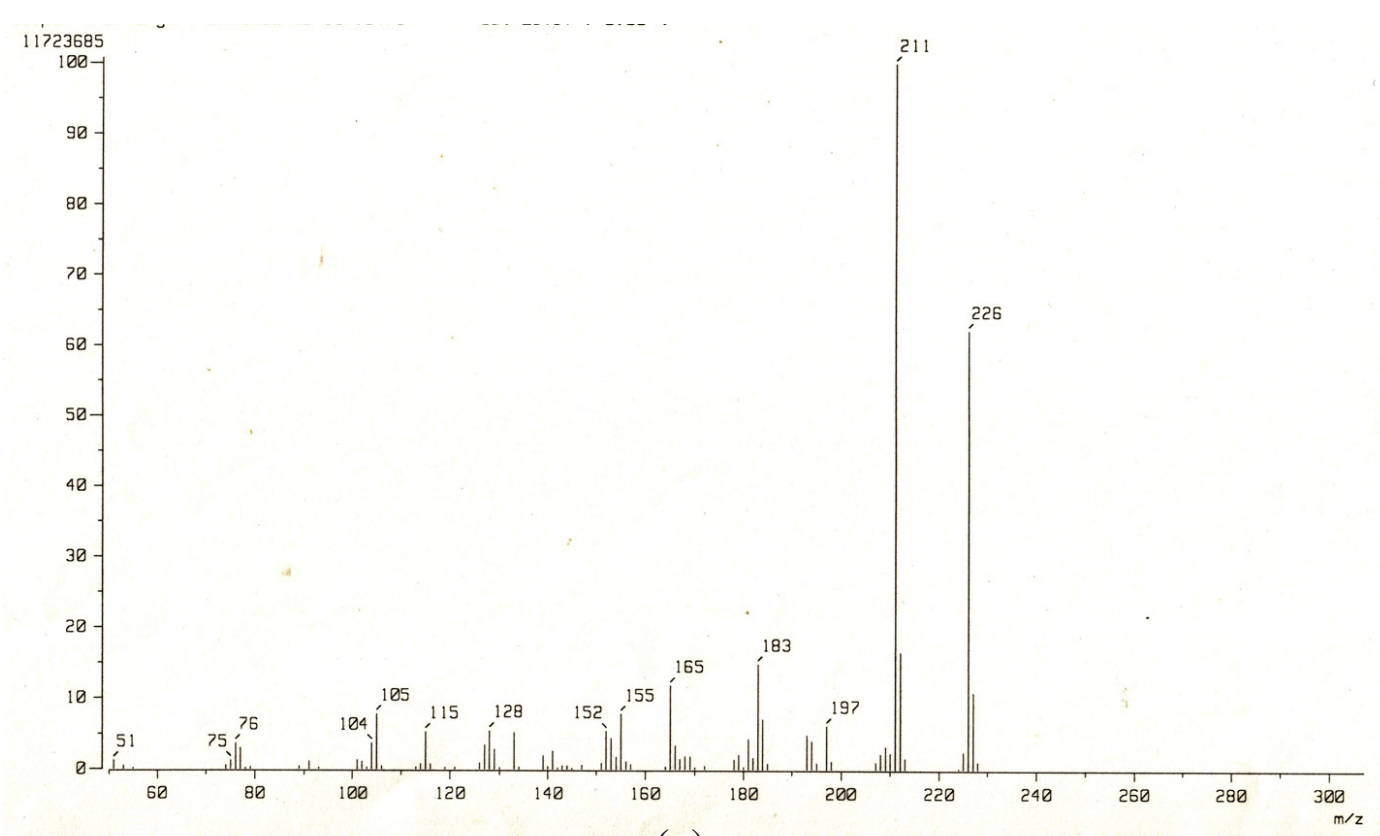

(a)

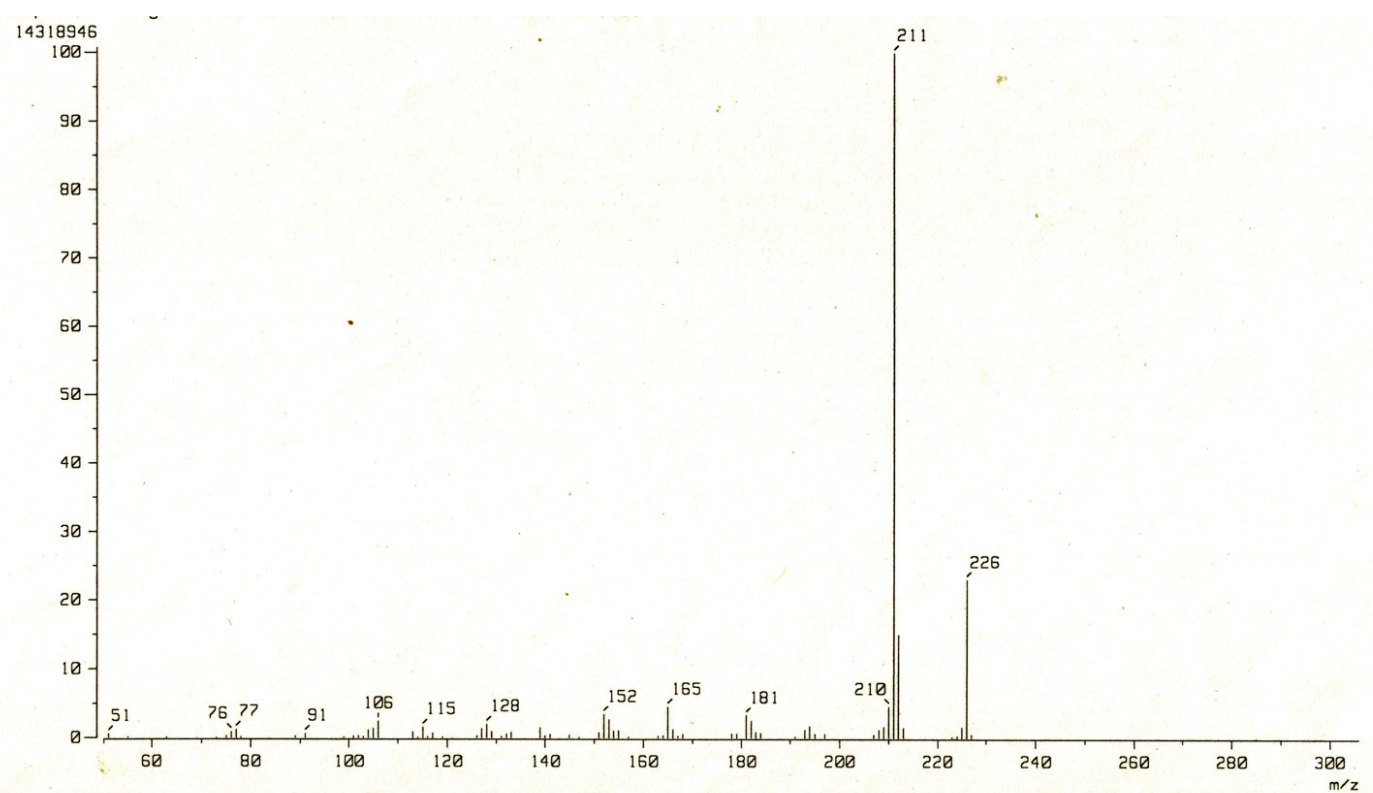

(b)

Figure 3. Mass spectra of desoxylapachol (a) and isodesoxylapachol (b).

that the quantity of tectoquinone and its ratio to desoxylapachol appears to be a good indicator of antifungal properties, while Thulasidas and Bhat (2007) observed that naphtaquinone is the single major compound which determines the decay resistance of teak. Sumthong (2006) found that both tectoquinone and desoxylapachol are active compounds against Aspergillus niger. These findings confirmed the presence of toxic components in the sapwood and heartwood of young trees. In addition, they confirmed that no aging or detoxification of teak extractives occurs by the time a given tree is
51 years old. The total quinone content (TQC) of each part obtained in this study is displayed in Figure 4. Tectol, palmitic acid and squalene have never been mentioned as factors in natural durability.

It has been reported that the wood regions near the pith and sapwood were much less resistant to termite and fungal attack than the outer heartwood (Bhat and Florence, 2003; Bhat et al., 2005; Da Costa et al., 1959; Kokutse et al., 2006; Narayanamurti et al., 1962; Rudman, 1967). The lower natural durability of younger trees has been demonstrated by Da Costa 
Table I. Contents of major components (\% of oven-dry wood) in the ethanol-benzene extract of teakwood trees aged 8,30 and 51 (radial position).

\begin{tabular}{|c|c|c|c|c|c|c|c|}
\hline \multirow[t]{2}{*}{ Components } & \multicolumn{4}{|c|}{ Outer sapwood } & & \multicolumn{2}{|c|}{ Inner sapwood } \\
\hline & \multicolumn{2}{|c|}{$8 \mathrm{y}$} & $30 \mathrm{y}$ & $51 \mathrm{y}$ & & $8 \mathrm{y}$ & $30 \mathrm{y}$ \\
\hline Desoxylapachol & \multicolumn{2}{|c|}{ nd } & $\operatorname{tr}$ & nd & & $\operatorname{tr}$ & nd \\
\hline Palmitic acid & \multicolumn{2}{|c|}{$0.04(0.01) \mathrm{ab}$} & $0.03(0.007) \mathrm{a}$ & nd & & $0.04(0.04) \mathrm{ab}$ & $0.03(0.01) \mathrm{a}$ \\
\hline Lapachol & \multicolumn{2}{|c|}{$\operatorname{tr}$} & $\operatorname{tr}$ & $\operatorname{tr}$ & & $0.01(0.01) \mathrm{a}$ & $0.01(0.002) \mathrm{a}$ \\
\hline Isodesoxylapachol & \multicolumn{2}{|c|}{$\operatorname{tr}$} & $0.02(0.006) \mathrm{a}$ & $0.01(0.004) \mathrm{ab}$ & & $0.01(0.01) \mathrm{a}$ & $\operatorname{tr}$ \\
\hline UN1 & \multicolumn{2}{|c|}{ nd } & $\operatorname{tr}$ & nd & & $\operatorname{tr}$ & nd \\
\hline Tectoquinone & \multicolumn{2}{|c|}{$0.02(0.02) \mathrm{a}$} & $0.03(0.02) \mathrm{a}$ & $0.03(0.004) \mathrm{a}$ & & $0.03(0.02) \mathrm{a}$ & $0.05(0.03) \mathrm{a}$ \\
\hline $\mathrm{UN} 2$ & \multicolumn{2}{|c|}{ nd } & $\operatorname{tr}$ & nd & & $\operatorname{tr}$ & nd \\
\hline Squalene & \multicolumn{2}{|c|}{$0.02(0.02) \mathrm{a}$} & $0.07(0.01) \mathrm{a}$ & $0.07(0.03) \mathrm{a}$ & & $0.05(0.02) \mathrm{a}$ & $0.15(0.04) \mathrm{a}$ \\
\hline Tectol & \multicolumn{2}{|c|}{$\operatorname{tr}$} & $\operatorname{tr}$ & $\operatorname{tr}$ & $\operatorname{tr}$ & $\operatorname{tr}$ & \\
\hline \multirow[t]{2}{*}{ Components } & \multicolumn{3}{|c|}{ Outer heartwood } & \multicolumn{2}{|c|}{ Middleheartwood } & \multicolumn{2}{|c|}{ Inner heartwood } \\
\hline & $8 \mathrm{y}$ & $30 \mathrm{y}$ & $51 \mathrm{y}$ & $30 \mathrm{y}$ & $51 \mathrm{y}$ & $30 \mathrm{y}$ & $51 \mathrm{y}$ \\
\hline Desoxylapachol & nd & $0.31(0.48) \mathrm{b}$ & $0.19(0.15) \mathrm{ab}$ & $0.02(0.03) \mathrm{a}$ & $0.13(0.23) \mathrm{ab}$ & $0.03(0.03) \mathrm{a}$ & $0.03(0.05) \mathrm{a}$ \\
\hline Palmitic acid & $0.04(0.01) \mathrm{ab}$ & $0.07(0.02) \mathrm{b}$ & $0.08(0.02) \mathrm{c}$ & $0.03(0.01) \mathrm{a}$ & $0.04(0.01) \mathrm{ab}$ & $0.06(0.01) a b c$ & $0.04(0.01) \mathrm{ab}$ \\
\hline Lapachol & $0.10(0.13) \mathrm{ab}$ & $0.25(0.26) \mathrm{b}$ & $0.16(0.32) \mathrm{ab}$ & $0.11(0.07) \mathrm{ab}$ & $0.03(0.06) \mathrm{a}$ & $0.10(0.08) \mathrm{ab}$ & $0.03(0.04) \mathrm{a}$ \\
\hline Isodesoxylapachol & $0.05(0.04) \mathrm{ab}$ & $0.17(0.10) b c$ & $0.34(0.23) \mathrm{d}$ & 0.12 (0.09)bcd & $0.26(0.11) \mathrm{cd}$ & $0.19(0.16) b c$ & $0.15(0.06) a b c$ \\
\hline UN1 & nd & $0.01(0.03) \mathrm{a}$ & $0.01(0.02) \mathrm{a}$ & $0.03(0.07) \mathrm{a}$ & $0.12(0.21) \mathrm{a}$ & $0.17(0.30) \mathrm{a}$ & $0.19(0.21) \mathrm{a}$ \\
\hline Tectoquinone & $0.20(0.06) b c$ & $0.16(0.06) \mathrm{abc}$ & $0.24(0.22) b c$ & $0.11(0.08) \mathrm{ab}$ & $0.27(0.07) \mathrm{c}$ & $0.19(0.06) b c$ & $0.30(0.16) \mathrm{c}$ \\
\hline UN2 & nd & $0.06(0.06) \mathrm{a}$ & $0.21(0.18) \mathrm{b}$ & $0.02(0.02) \mathrm{a}$ & $0.09(0.06) \mathrm{a}$ & $0.03(0.02) \mathrm{a}$ & $0.02(0.02) \mathrm{a}$ \\
\hline Squalene & $0.08(0.04) \mathrm{a}$ & $0.50(0.22) b c$ & $1.08(0.39) \mathrm{d}$ & $0.42(0.13) b c$ & $0.50(0.18) b c$ & $0.56(0.38) \mathrm{c}$ & $0.24(0.15) \mathrm{ab}$ \\
\hline Tectol & $0.08(0.04) \mathrm{a}$ & $0.26(0.06) \mathrm{bc}$ & $0.47(0.31) \mathrm{e}$ & $0.19(0.08) \mathrm{abc}$ & $0.29(0.14) \mathrm{cd}$ & $0.30(0.22) \mathrm{cd}$ & $0.16(0.11) a b c$ \\
\hline
\end{tabular}

Mean of 5 trees ( 8 and 51 years old) and 4 trees (30 years old), with the standard deviation in parentheses. The same letters in the same row are not significantly different at $p<5 \%$ by Duncan's test. nd $=$ Spectroscopically not detected; $\operatorname{tr}=$ trace (detected, the value $<0.01 \%$ ).

Table II. Pearson's correlation coefficients between total extractive content and extractive component contents.

\begin{tabular}{|c|c|c|c|c|c|c|c|c|c|}
\hline & TEC & DES & PAL & LAP & ISO & UN1 & TEQ & UN2 & SQU \\
\hline$\overline{D E S}$ & $0.46^{* * *}$ & & & & & & & & \\
\hline PAL & $0.52 * *$ & 0.24 & & & & & & & \\
\hline LAP & $0.45 * *$ & $0.61 * *$ & $0.39 * *$ & & & & & & \\
\hline ISO & $0.79 * *$ & $0.54 * *$ & $0.48 * *$ & $0.64 * *$ & & & & & \\
\hline UN1 & 0.09 & -0.01 & -0.00 & 0.06 & 0.07 & & & & \\
\hline TEQ & $0.64 * *$ & 0.12 & $0.34 * *$ & $0.27 *$ & $0.54 * *$ & 0.22 & & & \\
\hline UN2 & $0.56 * *$ & $0.55 * *$ & $0.46^{* *}$ & $0.47 * *$ & $0.73^{* *}$ & -0.05 & $0.30 *$ & & \\
\hline SQU & $0.74 * *$ & $0.49 * *$ & $0.60 * *$ & $0.45^{* *}$ & $0.78 * *$ & 0.12 & $0.47 * *$ & $0.72 * *$ & \\
\hline TOL & $0.84 * *$ & $0.46^{* *}$ & $0.56 * *$ & $0.62 * *$ & $0.91 * *$ & 0.09 & $0.61 * *$ & $0.76^{* *}$ & $0.84 * *$ \\
\hline
\end{tabular}

Significant at the $1 \%$ level, $*$ significant at the $5 \%$ level; TEC $=$ total extractive content, ISO $=$ isodesoxylapachol, PAL $=$ palmitic acid, LAP $=$ lapachol, DES = desoxylapachol, UN1 = unidentified compound $1, \mathrm{TEQ}=$ tectoquinone, $\mathrm{UN} 2=$ unidentified compound $2, \mathrm{SQU}=$ squalene, TOL $=$ tectol.

et al., 1958, Haupt et al., 2003, Narayanamurti et al., 1962. In other species, good correlations have been found between extent of decay and extractive content in Larix sp. (Windeisen et al., 2002), Pinus sylvestris (2003) and Quercus petraea (Guilley et al., 2004), with the extractive content found to be greater in the outer heartwood than in the inner heartwood zone.

As would be expected, the sapwood values were significantly lower than heartwood for TEC, TQC and individual toxic compound contents. Levels of TEC, TQC, isodesoxylapachol and its isomer in the $\mathrm{OH}$ of 51-year-old groups were significantly higher than in the $\mathrm{OH}$ of 8-year-old trees. The $\mathrm{OH}$ of 30- and 51 year-old trees differed only in isodesoxylapachol content. The comparison between the $\mathrm{OH}$ and $\mathrm{IH}$ showed significant differences in desoxylapachol levels of 30-year-old trees, as well as the TEC and isodesoxylapachol levels of 51year-old trees, but there was no significant difference in TQC levels in either 30- or 51-year-old trees. In the case of individual substances, the significant differences in desoxylapachol and/or its isomer content suggest that the wood from younger trees will be less durable due to the lower contents of these compounds, as is the case with teak plantations.

The pattern of TQC levels in the heartwood corresponded well with the data from the previous results on mass loss (Tab. II) due to termite attacks, where the mass losses in the $\mathrm{OH}$ of 51-year-old trees were significantly lower than in the $\mathrm{OH}$ of 8-year-old trees; the mass losses between the $\mathrm{OH}$ and IH in both 30- and 51-year-old trees did not differ significantly. 
Table III. Survival rate and mass loss against Reticulitermes speratus in 2 weeks of observation of teakwood by age and radial position. Mean of 5 trees ( 8 and 51 years old) and 4 trees (30 years old), with the standard deviation parentheses. The same letters in the same column are not significantly different at $p<5 \%$ by Duncan's test.

\begin{tabular}{|c|c|c|c|c|}
\hline \multirow[t]{2}{*}{ Tree age $(y)$} & \multirow[t]{2}{*}{ Position } & \multicolumn{2}{|c|}{ Survival rate $(\%)$} & \multirow[t]{2}{*}{ Mass loss (mg) } \\
\hline & & First week & Second week & \\
\hline \multirow[t]{3}{*}{8} & Outer sapwood & $82.72(16.42) \mathrm{a}$ & $55.85(24.68) \mathrm{a}$ & $27.68(8.05) \mathrm{d}$ \\
\hline & Inner sapwood & 84.00 (16.49) a & $47.50(29.33) \mathrm{a}$ & $31.81(14.78) \mathrm{d}$ \\
\hline & Outer heartwood & $57.00(22.81) \mathrm{b}$ & $37.66(23.18) b$ & $7.45(5.39) \mathrm{b}$ \\
\hline \multirow{5}{*}{30} & Outer sapwood & $70.60(13.92) \mathrm{a}$ & $24.33(18.56) \mathrm{b}$ & $14.52(6.78) \mathrm{c}$ \\
\hline & Inner sapwood & 70.66 (14.24) a & $24.18(22.60) b$ & $7.84(6.23) b$ \\
\hline & Outer heartwood & $59.55(18.43) \mathrm{b}$ & $29.81(21.09) \mathrm{b}$ & $4.07(3.32) \mathrm{ab}$ \\
\hline & Middle heartwood & $58.18(12.85) \mathrm{b}$ & $28.83(16.56) \mathrm{b}$ & $3.18(2.71) a b$ \\
\hline & Inner heartwood & $54.60(25.22) \mathrm{b}$ & $25.81(13.15) b$ & $5.69(4.36) \mathrm{ab}$ \\
\hline \multirow{4}{*}{51} & Outer sapwood & $58.42(19.28) \mathrm{b}$ & $23.73(15.15) b$ & $6.30(4.34) \mathrm{ab}$ \\
\hline & Outer heartwood & $53.28(13.09) \mathrm{b}$ & $27.20(13.81) b$ & 1.37 (1.06) a \\
\hline & Middle heartwood & $44.66(15.35) \mathrm{b}$ & $27.60(9.89) b$ & $1.39(1.22) \mathrm{a}$ \\
\hline & Inner heartwood & $54.53(25.52) \mathrm{b}$ & $31.33(14.57) \mathrm{b}$ & $4.72(3.46) \mathrm{ab}$ \\
\hline Pine control & & $96.67(1.15)$ & $88.67(2.30)$ & $52.41(5.69)$ \\
\hline Starvation & & $58.0(4.0)$ & $16.6(13.3)$ & - \\
\hline
\end{tabular}

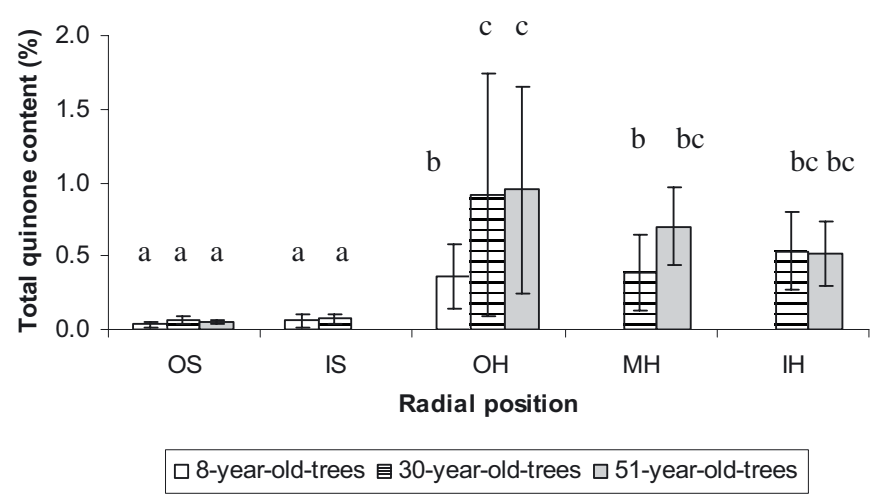

Figure 4. Total quinone content $(\%)$ of teakwood by age and radial position. Mean of 5 trees ( 8 and 51 years old) and 4 trees (30 years old), with the standard deviation in the error bar. The same letters are not significantly different at $p<5 \%$ by Duncan's test. OS = Outer sapwood, IS = inner sapwood, $\mathrm{OH}=$ outer heartwood, $\mathrm{MH}=$ middle heartwood, $\mathrm{IH}=$ inner heartwood.

However, the high natural termite resistance levels in the OS of 51-year-old trees, which contain low levels of TQC, could not be explained satisfactorily. This implies that other factors must be contributing and the reasons for the high resistance in that region should be investigated more thoroughly.

\subsection{Relationship between extractive compounds and natural termite resistance properties}

Correlation analysis between natural termite resistance parameters and quinone compounds is shown in Table II. There was no significant relationship between the contents of lapachol or desoxylapachol and natural termite resistance parameters. The correlation coefficient between the survival rate in the first week and the content of extractive compounds was slightly greater than the correlation coefficient between the
Table IV. Pearson's correlation coefficients between natural termite resistance parameters and extractive component contents.

\begin{tabular}{lccc}
\hline Extractive content & \multicolumn{3}{c}{ Natural termite resistance } \\
\cline { 2 - 4 } & $\begin{array}{c}\text { Survival rate in } \\
\text { the first week }\end{array}$ & $\begin{array}{c}\text { Survival rate } \\
\text { in the second week }\end{array}$ & Mass loss \\
\hline Desoxylapachol & -0.19 & -0.19 & -0.25 \\
Lapachol & -0.18 & -0.16 & -0.25 \\
Isodesoxylapachol & $-0.38^{* *}$ & $-0.33^{*}$ & $-0.47^{* *}$ \\
Tectoquinone & $-0.46^{* *}$ & $-0.35^{* *}$ & $-0.49^{* *}$ \\
Total quinone & $-0.38^{* *}$ & $-0.33^{*}$ & $-0.47^{* *}$ \\
\hline
\end{tabular}

** Significant at the $1 \%$ level; * significant at the $5 \%$ level.

survival rate in the second week and the content of extractive compounds. The survival rate in the first week was correlated best with the content of tectoquinone $(r=-0.46)$. The highest correlation coefficient was observed between the mass loss and the content of tectoquinone $(r=-0.49)$, followed by the mass loss and the content of isodesoxylapachol $(r=-0.47)$. This means that teak is more resistant when it contains higher amounts of these compounds. The relationships between the mass loss and the amount of tectoquinone and isodesoxylapachol are illustrated in Figure 5. These findings may support Rudman et al. (1958), who concluded that although tectoquinone exhibited strong antitermitic properties, this compound is not the sole cause of termite resistance. However, the degree of correlation between the natural termite resistance characteristics and total quinone content was not as strong as might be expected.

The relatively weak degree of correlation obtained in this study is interpreted as reflecting the complex nature of teak extractives (Sandermann and Simatupang, 1966; Yamamoto et al., 1998), as well as the complex interaction between heartwood extractives and its durability. It has been proved that although teak heartwood contains toxic components, they merely deter termites under natural conditions (Lukmandaru 


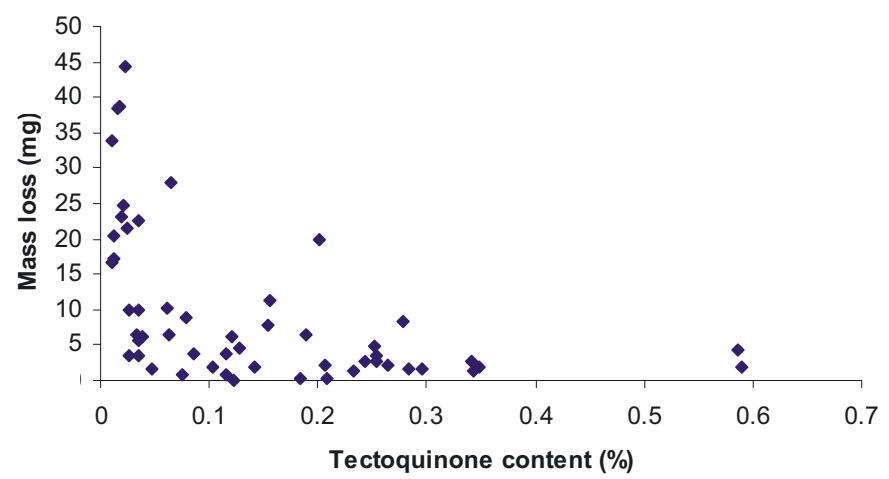

(a)

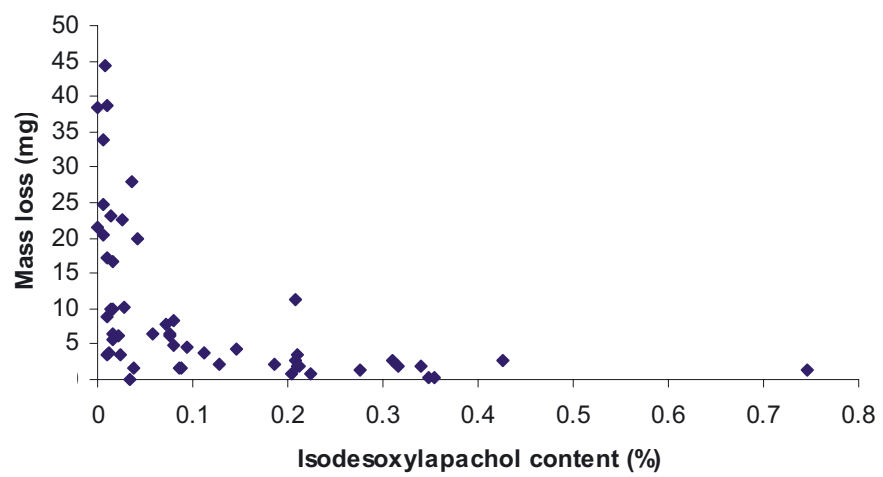

(b)

Figure 5. Scatterplots between mass loss against Reticulitermes speratus in 2 weeks of observation and the amount of tectoquinone (a) and isodesoxylapachol (b).

and Takahashi, 2008; Rudman et al., 1967). Therefore, another method using purified extractive components should be attempted in order to understand the natural durability of teak. Previous studies with other species such as Cinnamomum camphora (Hashimoto et al., 1997) showed that variation in termite resistance could be explained by the concentration of the largely responsible component (camphor). Significant correlations were reported between ellagitannin content and decay resistance of Quercus petraea (Guilley et al., 2004), whereas the variation in decay resistance of Larix sibrica (Venalainen et al., 2006) showed a good correlation with taxifolin content. In contrast, Taylor et al. (2006) found that variations in extractive components explained relatively little the variation in fungal and termite resistance of Thuja plicata and Chamaecyparis nootkanensis wood.

\section{CONCLUSION}

Tree age and radial position were shown to influence the presence and amount of quinone components detected in teak extracts. Thus, these results suggest that the variability in the TQC and individual quinone contents may influence the natural durability level of teak. Considerable variation was observed in the extractive component contents of wood samples taken from the same site. The toxic quinone component contents were positively correlated with total extractive content, with the highest correlation degree being observed in the isodesoxylapachol content. The amount of tectoquinone and isodesoxylapachol was significantly correlated with natural termite resistance properties. Variation in the individual active quinone contents, however, could not adequately explain the variation in natural termite resistance.

Acknowledgements: This work was supported by the Ministry of Education, Culture, Sports, Science and Technology, Japan. We also thank Dr. Tatsuya Ashitani at our university for helping with mass spectrum analysis, and Andri Setyawan and Mufti Wibowo (Brebes Forestry Service) for helping with sample preparation.

\section{REFERENCES}

Bhat K.M. and Florence E.J.M., 2003. Natural decay resistance of juvenile teak wood grown in high input plantations. Holzforschung 57: 453-455.

Bhat K.M., Thulasidas P.K., Florence E.J.M., and Jayaraman K., 2005. Wood durability of home-garden teak against brown-rot and whiterot fungi. Trees 19: 654-660.

Da Costa E.W.B., Rudman P., and Gay F.J., 1958. Investigations on the durability of Tectona grandis. Empire Forestry Review 37: 291-298.

Da Costa E.W.B., Rudman P., and Gay F.J., 1961. Relationship of growth rate and related factors to durability in Tectona grandis. Empire Forestry Review 40: 308-319.

Guilley E., Charpentier J.P., Ayadi N., Snakkers G., Nepveu G., and Charrier B., 2004. Decay resistance against Coriolus versicolor in Sessile oak (Quercus petraea Liebl.): analysis of the between-tree variability and correlations with extractives, tree growth and other basic wood properties. Wood Sci. Technol. 38: 539-554.

Hashimoto K., Ohtani Y., and Sameshima K., 1997. The termiticidal activity and its transverse distribution in camphor (Cinnamomum camphora) wood. Mokuzai gakkaishi 43: 566-573.

Haupt M., Leithoff H., Meier D., Puls J., Richter H.G., and Faix O., 2003. Heartwood extractives and natural durability of plantation-grown teakwood (Tectona grandis L.) - a case study. Holz Roh- Werkst. 61: 473-474.

Khan, R.M. and Mlungwana S.M., 1999. 5-Hydroxylapachol: a cytotoxic agent from Tectona grandis. Phytochemistry 50: 439-442.

Kokutse A.D., Stokes A., Bailleres H., Kokou K., and Baudasse C., 2006. Decay resistance of Togolese teak (Tectona grandis L.) heartwood and relationship with colour. Trees 20: 219-223.

Lemos T.G., Costa S.M., Pessoa O.L., and Braz Filho R., 1999. Total Assignment of ${ }^{1} \mathrm{H}$ and ${ }^{13} \mathrm{C}$ NMR Spectra of Tectol and Tecomaquinone. Magn. Reson. Chem. 37: 908-911.

Lukmandaru G. and Takahashi K., 2008. Variation in the natural termite resistance of teak (Tectona grandis Linn fil.) wood as a function of tree age. Ann. For. Sci. 65: 708 .

Narayanamurti D., George J., Pant H.C., and Singh J., 1962. Extractives in teak. Sylvae Genet. 11: 57-63.

Nault J., 1988. Radial distribution of thujaplicins in old growth and second growth western red cedar (Thuja plicata Donn). Wood Sci. Technol. 22: 73-80.

Perry N.B., Blunt J.W., and Munro M.H.G., 1991. A cytotoxic and antifungal 1,4 naphtaquinone and related compounds from a New Zealand brown alga, Landsburgia quercifolia. J. Nat. Prod. 54: 978-985.

Prida A., Boulet J.C., Ducousso A., Nepveu G., and Puech J.L., 2006. Effect of species and ecological conditions on ellagitannin content in 
oak wood from an even-aged and mixed stand of Quercus robur $\mathrm{L}$. and Quercus petraea Liebl. Ann. For. Sci. 63: 415-424.

Prida A., Ducousso A., Petit R.J., Nepveu G., and Puech J.L., 2007. Variation in wood volatile compounds in a mixed oak stand: strong species and spatial differentiation in whisky-lactone content. Ann. For. Sci. 64: 313-320.

Rudman P., Da Costa E.W.B., and Gay F.J., 1967. Wood quality in plus trees of teak (Tectona grandis L.f.): an assessment of decay and termite resistance. Sylvae Genet. 16: 102-105.

Rudman P., Da Costa E.W.B., Gay F.J., and Wetherly A.H., 1958. Relationship of tectoquinone to durability in Tectona grandis. Nature 181: 721-722.

Rudman P. and Gay F.J., 1961. The causes natural durability in timber part VI. Measurement of anti-termite properties of anthraquinones from Tectona grandis L.f. by rapid semi-micro method. Holzforschung 15: 117-120.

Sandermann W. and Dietrichs H.H., 1959. Chemische untersuchungen an Teakholz. Holzforschung 13: 137-148.

Sandermann W. and Simatupang M.H., 1966. On the chemistry and biochemistry of teakwood (Tectona grandis L.f.). Holz Roh-Werkst 24: 190-204.

Shibutani S., Takata K., and Doi S., 2007. Quantitative comparisons of antitermite extractives in heartwood from the same clones of Cryptomeria japonica planted at two different sites. J. Wood Sci. 53: 285-290.

Sumthong P., Damveld R.A., Choi Y.H., Arentshorst M., Ram A.F.J., Van den Hondel C.A.M.J.J., and Verpoorte R., 2006. Activity of quinones from teak (Tectona grandis) on fungal cell wall stress. Planta Med. 72: 943-944.

Taylor A.M., Gartner B.L., Morrell J.J., and Tsunoda K., 2006. Effects of heartwood extractive fractions of Thuja plicata and Chamaecyparis nootkanensis on wood degradation by termites or fungi. J Wood Sci. 52: $147-153$.

Thulasidas P.K. and Bhat K.M., 2007. Chemical extractive compounds determining the brown-rot decay resistance of teak wood. Holz RohWerkst 65: 121-124.

Venäläinen M., Harju A.M., Kainulainen P., Viitanen H., and Nikulainen H., 2003. Variation in the decay resistance and its relationship with other wood characteristics in old Scots pines. Ann. For. Sci. 60: 409-417.

Venäläinen M., Harju A.M., Terziev N., Laakso T., and Saranpaa P., 2006. Decay resistance extractive content, and water sorption capacity of Siberian larch (Larix sibirica Lebed.) heartwood timber. Holzforschung 60: 99-103.

Windeisen E., Klassen A., and Wegener G., 2003. On the chemical characterization of plantation teakwood (Tectona grandis L.) from Panama. Holz Roh- Werkst. 61: 416-418.

Windeisen E., Wegener G., Lesnino G., and Schumacher P., 2002. Investigation of the correlation between the extractives content and natural durability in 20 cultivated larch trees. Holz Roh- Werkst. 60: 373-374.

Yamamoto K., Simatupang M.H., and Hashim R., 1998. Caoutchouc in teak wood (Tectona grandis L.f.): formation, location, influence on sunlight irradiation, hydrophobicity and decay resistance. Holz RohWerkst. 56: 201-209. 